\title{
Resilience in institutionalized adolescents without parental care in the state of Morelos México
}

\section{Resiliencia en adolescentes institucionalizados sin cuidados parentales en el Estado de Morelos México}

\author{
GOMEZ-ESQUIVEL, Dulce Areli* \& ORTIZ-RODRÍGUEZ, María Araceli
}

Universidad Autónoma del Estado de Morelos (UAEM)-Facultad de Comunicación Humana, Avenida Universidad 1001 Chamilpa, 6220, Cuernavaca, Mor.

Universidad Autónoma del Estado de Morelos (UAEM)- Facultad de Nutrición, UAEM, México, Avenida Universidad 100, Chamilpa 6220, Cuernavaca, Mor.

ID $1^{\text {st }}$ Author: Dulce Areli, Gómez-Esquivel / ORC ID: 0000-0002-6422-1983, CVU CONACYT ID: 956096

ID $1^{\text {st }}$ Coauthor: María Araceli, Ortiz-Rodríguez / ORC ID: 0000-0003-0847-0261, Researcher ID Thomson: T-3707-2018, CVU CONACYT ID: 449164

DOI: 10.35429/EJC.2020.10.6.6.10

Received April 08, 2020; Accepted June 30, 2020

\begin{abstract}
Introduction. Resilience has been proposed as a novel research topic in environments with vulnerable populations, since it promotes healthy development in the face of adverse circumstances. In the case of adolescents without parental care, foster care in social institutions has been one of the resources most used by the State to offer protection and guarantee the human rights of girls, boys and adolescents in Mexico, who may or may not present a disability and who lack a father, mother or guardian, for which by means of these institutions they guarantee the healthy development of minors. Objective. Analyze the levels of resilience in institutionalized adolescents without parental care, with and without disabilities. Method. Analytical transversal. The Asylum Anomie and Nominal Resilience Inventory (IAAR) was applied. 29 adolescents (men) with an age range of 12 to 19 years participated, 24 without disabilities (SD) and 5 with disabilities (CD). Statistical analysis was performed using the SPSS v.25 program. Results. 17 adolescents $(58.6 \%)$ presented resilience, $12(41.3 \%)$ did not present resilience according to the IAAR. Conclusions. In our study, more than half of institutionalized adolescents show resilience according to the IAAR.
\end{abstract}

Resilience, Adolescents, Institutionalization

\section{Resumen}

Introducción. La Resiliencia se ha propuesto como un novedoso tema de investigación en ambientes con poblaciones vulnerables, ya que promueve el sano desarrollo ante las circunstancias adversas. En caso de los adolescentes sin cuidados parentales el acogimiento en las instituciones sociales ha sido uno de los recursos más utilizados por el Estado para ofrecer protección y garantizar los derechos humanos de las niñas, niños y adolescentes en México, los cuales pueden presentar o no una discapacidad y que carecen de padre, madre o tutor, por lo cual por medio de estas instituciones garantizan el sano desarrollo de los menores de edad. Objetivo. Analizar los niveles de resiliencia en adolescentes institucionalizados sin cuidados parentales, con y sin discapacidad. Método. Transversal analítico. Se aplicó el Inventario de Anomia Asiliente y Resiliencia Nomica (IAAR). Participaron 29 adolescentes (hombres) con un rango de edad de 12 a 19 años, 24 sin discapacidad (SD) y 5 con discapacidad (CD). El análisis estadístico se realizó por el programa SPSS v.25. Resultados. 17 adolescentes (58.6\%) presentaron resiliencia, 12 (41.3\%) no presentaron resiliencia de acuerdo el IAAR. Conclusiones. En nuestro estudio más de la mitad de los adolescentes institucionalizados presentan resiliencia de acuerdo al IAAR.

Resiliencia, Adolescentes, Institucionalización

Citation: GOMEZ-ESQUIVEL, Dulce Areli \& ORTIZ-RODRÍGUEZ, María Araceli. Resilience in institutionalized adolescents without parental care in the state of Morelos México. ECORFAN Journal-Republic of Colombia. 2020. 6-10: 610

$\dagger$ Researcher contributing as first author. 


\section{Introduction}

\section{Orphans, institutionalized and violated}

In the world there are millions of adolescents without institutionalized parental care (ASCPI), some of the most frequent circumstances of why minors are separated from their parents and are taken to a social institution are: due to situations such as poverty, lack of access to essential goods, abuse in all its aspects, abandonment that occurs when caring for their children, illnesses or some type of disability that minors present (Red Latinoamericana de Fostering Familiar, 2011).

A social assistance institution (IAS) for minors or also called a home, is an assistance establishment that provides accommodation, maintenance and other services to orphaned, homeless, abandoned or foundling minors, due to abandonment, separation, abuse and mistreatment; problems on the part of the parents or inability to take care of the minors, whether due to poverty or physical or mental illness, difficulties on the part of the parents with alcohol and / or drug abuse, due to lack of will (refusal ) to take care of their children, disability and loss of parental authority due to abuse of minors in all its contexts and neglect, because the parents were imprisoned, or the family has suffered a natural disaster or war (Unicef, 2013).

Another way of calling the IAS is orphanage, orphanage, hospice, nursery, among others, in the same way there are accommodations that serve adolescents who cannot be cared for by their parents due to different reasons, so that although they have their parents Parents often resort to these accommodations to take care of their children for part of the week or continuously, however, for ASCPIs who are there permanently, the adoption process is also considered (INEGI, 2015).

Some of the IAS also open their doors to minors who were abandoned by their parents because they had disabilities, for which institutionalized minors could be doubly vulnerable. In 2005, it was estimated that there were at least 2.2 million children in the world living in orphanages; an orphanage is considered on two scales; the first scale is when they serve around 15 minors, and the second scale is considered larger when they serve 16 infants onwards.
In 2009, this figure was alarming, since it was estimated to be almost four times its 2005 figures, since it was announced that the number of minors who lack parental care is close to eight million minors who are living in IAS, and in Mexico the data is no less dire because it was assessed that just over 412, 450 (four hundred twelve thousand four hundred fifty) minors were deprived of the care of their parents, and of those 29,310 (twenty-nine thousand three hundred ten) were in the 703 (seven hundred three) institutions focused on the protection and foster care of minors (Merz and MacCall, 2011), however in Mexico and the world there are no exact statistics on the number of minors without parental care. According to Ferrán Casas "the best way to ignore the ASCPIs is to have few statistics on the situation of the child population" (Ferran, 2010). In this context, the number of orphanages increases, and in some parts of the world it seems to have no control (The Faith to Action Initiative, 2014).

\section{Effects of Institutionalization}

There are different repercussions for adolescents who were forced to grow up in one or different institutes of social assistance, and there are many studies dating back to the effects that institutionalization can have on their physical, intellectual and social development. Vivian \& Barreiro (2015) explain that chronic adversities, as well as the context in which adolescents develop, are some of the variables that could directly interfere with their development.

Children from zero to three years old who go to an IAS for different reasons, register up to four months of delay in their development and learning, for each year they spend in these public places, The events experienced in adolescents can affect their cognitive development and affective at different levels of intensity and in different ways (Elliot \& Carne, 2001, Runyon \& Kenny, 2002) "Studies suggest that the institution may or may not function as a social support network depending on the perception of the adolescent" (Vivian and Barreiro 2015). 
There are also different investigations that have supported the repercussions in different areas of the psychological and social development of minors who have had to grow up in social institutions, designated as homes, such is the case of the investigation carried out by Abaid (2008) who, through a study carried out on parenting in institutionalized adolescents, revealed that ASCPIs present depressive symptoms above average, in addition to $\mathrm{c}$ onstant stressful events, likewise the research carried out by Fernandez-Daza \& FernandezParra (2013) about behavioral problems and psychosocial competencies in institutionalized children and adolescents shows how they present lower psychosocial skills and academic unlike minors who live with their parents.

In Table 1 we can see the studies that have been carried out over time in institutionalized minors and their results in different fields.

\begin{tabular}{|c|c|c|}
\hline Researcher & Study and Field & Results \\
\hline Spitz (1940) & $\begin{array}{l}\text { Observation of } \\
\text { institutionalized } \\
\text { children } \\
\text { (Psychology) }\end{array}$ & $\begin{array}{l}\text { Hospitalism } \\
\text { syndrome, motor } \\
\text { slowness, } \\
\text { withdrawal, lack of } \\
\text { appetite, deficit in } \\
\text { motor coordination, } \\
\text { passivity and high } \\
\text { comorbidity and } \\
\text { infant mortality. }\end{array}$ \\
\hline $\begin{array}{l}\text { Mary } \\
\text { Ainscow } \\
(1978)\end{array}$ & $\begin{array}{l}\text { (Strange } \\
\text { situation) } \\
\text { observation on the } \\
\text { types } \\
\text { attachment, } \\
\text { (Psychology). }\end{array}$ & $\begin{array}{l}\text { "Player syndrome" in } \\
\text { institutionalized } \\
\text { minors. }\end{array}$ \\
\hline $\begin{array}{l}\text { Danzelot } \\
(1998)\end{array}$ & $\begin{array}{l}\text { The Family Police } \\
\text { (Criminology) }\end{array}$ & $\begin{array}{l}\text { Typical portrait of } \\
\text { the future criminal }\end{array}$ \\
\hline $\begin{array}{l}\text { Susana } \\
\text { Rocha de } \\
\text { Abrew } \\
(2000)\end{array}$ & $\begin{array}{l}\text { Psychiatric } \\
\text { disorders in } \\
\text { adolescents raised } \\
\text { in institutions. } \\
\text { (Psychiatry) }\end{array}$ & $\begin{array}{l}\text { Depression } \\
\text { associated with } \\
\text { living in an } \\
\text { institution, } \\
\text { deceased or missing } \\
\text { mother, having poor } \\
\text { school performance } \\
\text { and poor hygiene } \\
\text { conditions. }\end{array}$ \\
\hline $\begin{array}{l}\text { Carrasco, } \\
\text { Rodríguez } \\
\& \quad \text { Mass } \\
(2001)\end{array}$ & $\begin{array}{l}\text { Behavioral } \\
\text { problems of a } \\
\text { sample of } \\
\text { institutionalized } \\
\text { minors with a } \\
\text { history of abuse. } \\
\text { (Psychology) }\end{array}$ & $\begin{array}{l}\text { There is a correlation } \\
\text { between } \\
\text { institutionalization } \\
\text { and delinquency } \\
\text { factors, somatic } \\
\text { anxiety, somatic } \\
\text { problems, } \\
\text { delinquency, non- } \\
\text { sociability and social } \\
\text { withdrawal. }\end{array}$ \\
\hline
\end{tabular}

Table 1 The impact of Institutionalization according to various studies

\section{The study of resilience in vulnerable groups}

In the field of exploration of vulnerable groups, resilience has been presented as a capacity that describes those people who can develop in a healthy way despite having adverse circumstances throughout their lives. Anzola, (2003) describes resilience as a capacity manifested by people from environments of deep need that are capable of rebuilding themselves despite difficulties.

There are two results in debate regarding adolescents who do not have parental care, the first of which is that adolescents who did not have or do not have the relevant parental care during early childhood do not have the skills to be functional people, On the contrary, there are studies that show that even though adolescents are institutionalized, they can present personal factors that help their psychological and social development, as shown by the study by Gianino (2012) who, through a study of resilience to institutionalized children and not institutionalized determined that there were no significant differences between the resilience factors of both groups. In this way, we can say that resilience is a capacity that can be fostered in all children and adolescents regardless of whether or not they are institutionalized, as Llobet suggests:

Resilience is not a personality trait, but rather that people are actors and sources of resilient adaptations, and families, schools, communities, social services are the scenario for promoting resilience, and they can propitiate and provide (or not) the deployment of protective factors (Llobet, 2008, p.87).

Previously, there was little research that took into account the educational, emotional and social needs of ASCPIs and only focused on the problems that institutionalization could trigger; However, the focus of new research, such as the study of resilience, proposes to focus on the strengths that these young people could develop.

\section{Methodology}

29 male adolescents between 12 and 17 years old were invited to participate, all of them without parental care, who were housed in a social assistance institute. 


\section{Instruments}

A sociodemographic data questionnaire was used. To determine the levels of resilience, the inventory of asylum anomie and nomic resilience (IAAR) (Flores, 2013) was used. The test consists of 35 items and has a Cronbach's alpha coefficient of 0.86 . The approximate duration of the test is 10 minutes to 15 minutes. Resilience levels are classified as follows: Very High Resilience (RMA) contains a score of 61100 ; high resilience (RA) contains a score of 4660 ; the mean resilience (RM) of $31-45$ points; low anomie $(\mathrm{AB})$ of 0-30 points; mean anomie (AM) from -1 to -30 points; high anomia (AA) from -31 to -45 points and; finally, very high anomie (AMA) -46 to -100 points.

\section{Analysis of data}

The data were analyzed in the Statistical Package for the Social Sciences (SPSS) program, version 25 . For the description of the sociodemographic data, frequencies and percentages were used.

\section{Ethical aspects}

Before the development of this investigation, the participants and their tutors were granted an informed consent letter, which contained the purpose, objectives and development of the research.

\section{Results}

In table 2 we can see the characteristics of the adolescents, most of whom indicated that they exercise an evangelical Christian religion, four of them indicated that they were Catholic and two of them indicated that they did not exercise or profess any religion. Regarding the school level, we can see through the data that three of them are in primary school, sixteen participants are in secondary school, five are in high school, and five are going to a center for education and attention to diversity that serves students with different abilities. . Finally, we can describe that thirteen of the participating adolescents never receive visits, six sometimes receive visits and ten of them always receive visits from relatives.

\begin{tabular}{|l|l|r|r|}
\multicolumn{2}{c|}{} & \multicolumn{2}{c|}{ F } \\
\hline \multirow{5}{*}{ Religion } & None & 2 & 6.9 \\
\cline { 2 - 4 } & Evangelical Christian & 23 & 79.3 \\
\cline { 2 - 4 } & Catholic & 4 & 13.8 \\
\hline School level & Primary & 3 & 10.3 \\
\cline { 2 - 4 } & High school & 16 & 55.2 \\
\cline { 2 - 4 } & High school & 5 & 17.2 \\
\cline { 2 - 4 } & CEADI & 5 & 17.2 \\
\hline Family visits & Never & 13 & 44.8 \\
\cline { 2 - 4 } & Sometimes & 6 & 20.7 \\
\cline { 2 - 4 } & Always & 10.0 & 34.5 \\
\hline
\end{tabular}

Table 2 Characteristics of the participants

In the results presented in table 3 we can see how most of our participants are between these two levels, followed by this result are medium resilience, then high resilience, high anomie and lastly very high anomie.

\begin{tabular}{|l|r|r|r|}
\hline \multicolumn{1}{|c}{ Resilience } & \multicolumn{1}{c|}{ SD } & CD & \multicolumn{1}{c|}{ Total } \\
\hline Very high anomia & 0 & 1 & 1 \\
\hline High anomie & 0 & 1 & 1 \\
\hline Mean anomie & 9 & 0 & 9 \\
\hline Low resilience & 7 & 3 & 10 \\
\hline Medium resilience & 3 & 0 & 3 \\
\hline High resilience & 3 & 0 & 3 \\
\hline Total & 22 & 5 & 27 \\
\hline Note. SD = No disability; CD = With disability \\
\hline
\end{tabular}

Table 3 Resilience of adolescents with and without disabilities

Describing our participants, we note that two of the participants who present a disability also present anomie, and three of them present low resilience, while adolescents without disabilities, nine of them present medium anomie, seven low resilience, three medium resilience and three resilience. high.

\section{Discussion}

Authors such as Carrasco Rodríguez \& Mass (2001) have found that institutionalization has managed to affect minors without parental care on a psychological level; Horrocks (1984) would also have pointed out that many young people have faced situations that are not appropriate for their age which could have affected their physical and mental development. Lastly, Vivian \& Barreiro 2015; Abaid, 2008; Fernández Daza \& Fernández Parra, 2013, have identified that institutionalization carries with it harmful repercussions on the physical, intellectual and social development of adolescents without parental care, which can have an impact on conflict resolution and in the educational field, as mentioned Lozano, Mera \& Salamanca (2015).

GOMEZ-ESQUIVEL, Dulce Areli \& ORTIZ-RODRÍGUEZ, María Araceli. Resilience in institutionalized adolescents without parental care in the state of Morelos México. ECORFAN Journal-Republic of Colombia. 2020 
However, there is also research carried out by Gianino (2012) that has shown us that institutionalized young people can also have resilience, as this study also shows.

\section{Conclusions}

In our study, more than half of institutionalized adolescents show resilience according to the IAAR. These results are similar to other studies that corroborate the capacity of adolescents without institutionalized parental care to develop resilience. However, adolescents in our country who live in a social assistance center have gone through adverse situations, which is why we must take special care in their training, since although they are capable of generating resilience like other adolescents with care It is also true that parents have gone through multiple events that can disrupt their lives. It is important to develop psychological intervention and resilience programs with the aim of promoting healthy development in adolescents with social assistance.

\section{Gratitude}

This research was funded by a grant from the National Quality Postgraduate Program (PNPC) of the National Council of Science and Technology (CONACYT), Mexico.

\section{References}

Anzola, M. (2003). La resiliencia como factor de protección, Investigación Arbitrada, 7 (22), 190200.

https://www.redalyc.org/pdf/356/35602209.pdf

Carrasco-Ortiz, M. Á., Rodríguez-Testal, J. F., $\&$ Hesse, B. M. (2001). Problemas de conducta de una muestra de menores institucionalizados con antecedentes de maltrato. Child abuse \& neglect, 25(6), 819-838. https://www.sciencedirect.com/science/article/a bs/pii/S0145213401002411

Donzelot, J. (1977). La policía de las familias. Valencia: Pre-textos, 1998.
Fernández-Daza, M.P. \& Fernández-Parra, A. (2013). Problemas de comportamiento y competencias psicosociales em niños y adolescentes institucionalizados. Revistas Científicas, Bogotá, vol. 12, $\mathrm{n}^{\circ} 3$. https://scholar.google.es/scholar?hl=es\&as_sdt $=0 \% 2 \mathrm{C} 5 \& \mathrm{q}=$ Problemas $+\mathrm{de}+$ comportamiento + $\mathrm{y}+$ competencias + psicosociales+em+ni\% $\mathrm{C} 3 \% \mathrm{~B}$ $10 s+y+$ adolescentes+institucionalizados.+Revis tas+Cient $\% \mathrm{C} 3 \%$ ADficas $\% 2 \mathrm{C}+\mathrm{Bog}$ ot $\% \mathrm{C} 3 \% \mathrm{~A} 1$ $\% 2 \mathrm{C} \& \mathrm{btnG}=$

Flores, O, D. (2013). La resiliencia nómica. Instituto Internacional de investigación para el desarrollo. Instituto internacional de investigación para el desarrollo A.C.

https://www.yumpu.com/es/document/read/142 19336/dr-dagoberto-flores-olvera-institutointernacional-de-investigacion-

Gianino, G, L. (2012). La resiliencia en los niños institucionalizados y no institucionalizados. UNIFE, 79-90. http://revistas.unife.edu.pe/index.php/avancesen psicologia/article/view/321

Horrocks, J. (1984). Psicología de la adolescencia. Ciudad de México: Trillas. http://p epsic.bvsalud.org/scielo.php?script=sci_nlinks \&ref $=1484854 \&$ pid=S0034$9690200800020001000007 \& \operatorname{lng}=\mathrm{pt}$

Instituto nacional de estadística y geografía. (2020). Censo de alojamiento de asistencia social. Red Nacional de Metadatos. https://www.inegi.org.mx/rnm/index.php/catalo g/217/datafile/F2/V171

Lozano Beltrán, Y. S., Mera Quiñonez, E., \& Salamanca Beltrán, E. P. (2015). Inclusión Escolar de Niños, Niñas y Adolescentes en Sistemas de Protección desde la visión de tres actores pertenecientes al sistema, (Tesis de licenciatura, Universidad Santo Tomas). http://repository.usta.edu.co/handle/11634/3569

United Nations Children's Fund. (4 de agosto de 2019). United Nations Children's Fund. Obtenido de huerfanos. https://www.unicef.org/es/huérfanos 